\title{
Analisis Kesulitan Mahasiswa dalam Menyelesaikan Masalah Konseptual Program Linier
}

\author{
Anwas Mashuri ${ }^{1)}$ \\ ${ }^{1)}$ STKIP Modern Ngawi, Indonesia \\ Email: anwas.mashuri.1@gmail.com
}

\begin{abstract}
This study aims to analyze student difficulties in solving conceptual problems in linear program courses. This study uses a qualitative descriptive method that aims to describe the difficulties and difficulties of students in solving problems in linear program courses. Difficulties with mathematical models and geometric approaches. The subjects in this study were students in the fifth semester of the Mathematics Education Study Program, Ngawi School of Teacher Training and Modern Education. Data collection was carried out based on the results of tests and interviews. The results showed that the difficulty of students in understanding the concept of linear programming was seen at every level of creative thinking skills. The difficulty found was that students had difficulty identifying problems and compiling mathematical models, analyzing models, and formulating conclusions and implementing the results.
\end{abstract}

Keywords : Difficulty Analysis, Linear Programming, Level Of Creative Thinking Skills, Students

\begin{abstract}
ABSTRAK
Penelitian ini bertujuan untuk menganalisis kesulitan mahasiswa dalam menyelesaikan masalah konseptual pada mata kuliah program linier. Penelitian ini menggunakan metode deskriptif kualitatif yang bertujuan untuk mendeskripsikan kesulitan serta kesulitan mahasiswa dalam menyelesaikan masalah pada mata kuliah program linier. Kesulitan terkait model matematika dan pendekatan geometri. Subjek dalam penelitian ini adalah mahasiswa semester V Program Studi Pendidikan Matematika, Sekolah Tinggi Ilmu Keguruan dan Ilmu Pendidikan Modern Ngawi. Pengambilan data dilaksanakan berdasarkan hasil tes dan wawancara. Hasil penelitian menunjukan bahwa kesulitan mahasiswa dalam memahami konsep program linier terlihat pada setiap tingkat keterampilan berpikir kreatif. Kesulitan yang ditemukan adalah mahasiswa kesulitan dalam mengidentifikasi persoalan dan menyusun model matematika, analisis model, dan merumuskan simpulan dan implementasi hasil.
\end{abstract}


Kata Kunci : Analisis Kesulitan, Program Linier, Tingkat Keterampilan Berpikir Kreatif, Mahasiswa.

\section{PENDAHULUAN}

Matematika adalah bagian penting dalam perkembangan ilmu pengetahuan dan teknologi dunia. Matematika juga berperan dalam menumbuh kembangkan kemampuan berpikir secara logis, secara sistematis dan secara kritis. Program linier berkaitan dengan penjelasan suatu kasus dalam dunia nyata sebagai suatu model matematik yang terdiri dari sebuah fungsi tujuan linier dengan beberapa kendala linier (Taha, 1996)

Program linier merupakan sebuah metode matematika yang dipergunakan untuk memecah optimum sebuah fungsi tujuan linier melalui pengalokasian organisasi atau perusahaan (Sigma \& 2015, n.d.). Program linier tidak hanya membuat kemampuan kognitif mahasiswa berkembang namun membantu juga dalam membentuk kemampuan mahasiswa dalam menganalisis kejadian atau masalah sehari-hari kedalam bentuk matematika.

Berdasarkan hasil observasi pada saat pembelajaran dalam kelas mahasiswa mengalami kesulitan dalam memahami masalah serta menyelesaikan masalah yang berkaitan dengan mata kuliah program linier. Materi program linier sebenarnya sudah dipelajari mahasiswa semasa SMA, namun ketika diberikan masalah atau soal yang berkaitan dengan program linier sebagian besar mahasiswa masih kesulitan dalam memahami dan menyelesaikannya.

Sebagian besar dosen telah mengamati bahwa para mahasiswa memiliki pemahaman yang salah terhadap mata kuliah program linier. Hal tersebut terlihat ketika nilai ujian tengah semester (UTS) sebagian besar mahasiswa memperoleh nilai yang rendah. Hal ini terjadi pada saat dosen mendiskusikan suatu permasalahan dengan bukti formal untuk menunjukan bagian dari masalah (Sciences \& 2012, n.d.).

Faktanya, masalah-masalah dalam program linier dianggap terlalu abstrak dan membingungkan. Akibatnya mahasiswa kesulitan pada saat mencoba menyelesaikan masalah, walaupun mahasiswa berbicara bahwa mereka paham. Mahasiswa akan mengalami kesulitan dalam memahami konsep program linier, sehingga mahasiswa akan menjadi pasif ketika pembelajaran yang akan 
mengakibatkan prestasi mahasiswa menurun. (Erdogan, Akkaya, \& Akkaya, 2009) program linier merupakan salah satu bidang ilmu matematika yang mempunyai pengaruh yang besar terhadap berpikir kreatif mahasiswa dalam pengembangan keterampilan mahasiswa. Berdasarkan hal tersebut maka dalam penelitian ini program linier berkaitan erat dengan berpikir kreatif.

Hasil penelitian (Alghafri, Social, \& 2014, n.d.) menyimpulkan bahwa strategi dalam pembelajaran yang berbasis keterampilan berpikir dapat mengembangkan tingkat kemampuan berpikir kreatif, sehingga pada pembelajaran program linier ini ditinjau dari kemampuan berpikir kreatif mahasiswa. Berpikir kreatif pada penelitian ini merupakan kemampuan mahasiswa guna menciptakan berbagai macam solusi serta cara pemecahan masalah. (Zdm \& 1997, n.d.) mengungkapkan bahwa ada tiga indikator berpikir kreatif dalam pemecahan masalah yang berguna untuk mengukur berpikir kreatif anak-anak serta orang dewasa sering digunakan "The Torrance Tests of Creative Thinking (TTCT)". Adapun tiga indikator utama dinilai dalam kreatifitas menggunakan TTCT meliputi kelancaran , fleksibilitas, dan kebaruan.

Tabel 1. Indikator Berpikir Kreatif dalam Pemecahan Masalah

Penyelesaian Masalah

Siswa menyelidiki masalah, dengan berbagai tujuan, metode solusi, atau penyelesaian
Kreativitas

Kelancaran

Siswa menyelesaikan dengan menggunakan satu metode; selanjutnya dengan metode lain mahasiswa mendiskusikan banyak Fleksibilitas metode pemecahan masalah.

Mahasiswa mengecek berbagai macam metode solusi atau pemecahan masalah; selanjutnya membuat metode dengan yang Kebaruan berbeda.

(Reviews \& 2011, n.d.) berpendapat bahwa pada penelitian ini menggunakan 5 Tingkat pemikir kreatif, yaitu:

\section{Tingkat 4}

Mahasiswa mampu menyelesaikan masalah yang diberikan dengan lebih dari satu alternatif penyelesaian atau mahasiswa mampu membuat permasalahan yang berbeda 
dengan lancar (fasih) dan fleksibel. Mahasiswa yang mencapai pada tingkat ini bisa dikatakan sangat kreatif.

\section{Tingkat 3}

Mahasiswa mampu memperlihatkan penyelesaian baru dengan menggunakan cara pemecahan yang berbeda (fleksibel) walaupun dalam menjawab tidak lancar sekalipun menggunakan cara yang berbeda (tidak luwes). Mahasiswa yang mencapai pada tingkat ini bisa dikatakan kreatif.

\section{Tingkat 2}

Mahasiswa mampu menghasilkan jawaban atau masalah yang berbeda yang berasal dari masalah umum walaupun tidak fleksibel atau lancar, atau dapat memperlihatkan cara penyelesaian yang berbeda walaupun belum memenuhi orisinalitas (kebaruan). Mahasiswa pada tingkat ini bisa disebut cukup kreatif.

\section{Tingkat 1}

Mahasiswa tidak bisa menghasilkan jawaban atau membuat masalah yang baru (kebaruan), namun mahasiswa bisa memperlihatkan jawaban baru dengan cara penyelesaian yang berbeda (fleksibel) atau mampu membuat beragam masalah (fasih). Mahasiswa pada tingkat ini dapat dikatakan tidak kreatif.

\section{Tingkat 0}

Mahasiswa tidak bisa menciptakan berbagai alternatif jawaban atau solusi atau menciptakan masalah yang beragam (fasih) dan fleksibel. Mahasiswa yang mencapai tingkat ini dapat dikatakan tidak kreatif

Berikut merupakan penjelasan tingkat keterampilan berpikir kreatif ditunjukan pada pada Tabel 2.

Tabel 2. Kategori Tingkat Keterampilan Berpikir Kreatif

\begin{tabular}{|c|c|c|c|c|c|c|c|c|}
\hline \multirow{2}{*}{ Indikator } & \multicolumn{8}{|c|}{ Tingkat } \\
\hline & & & 3 & & & & & $\mathbf{0}$ \\
\hline Kelancaran & $\sqrt{ }$ & $\sqrt{ }$ & $\sqrt{ }$ & - & - & - & $\sqrt{ }$ & - \\
\hline Fleksibilitas & $\sqrt{ }$ & - & $\sqrt{ }$ & $\sqrt{ }$ & $\sqrt{ }$ & - & - & - \\
\hline Kebaruan & $\sqrt{ }$ & $\sqrt{ }$ & - & $\sqrt{ }$ & - & $\sqrt{ }$ & - & - \\
\hline
\end{tabular}

Keterangan $: \sqrt{ }:$ memenuhi $;-:$ tidak memenuhi 
Berdasarkan paparan masalah yang diuraikan di atas bahwa perkembangan tingkat kemampuan berpikir kreatif mahasiswa pa mata kuliah program linier menjadi terhambat, karena kesulitan pemahaman mahasiswa pada mata kuliah program linier sehingga mengakibatkan penurunan hasil belajar mahasiswa. Oleh sebab itu, peneliti melihat dibutuhkannya analisis terhadap kesulitan mahasiswa dalam memahami konsep mata kuliah program linier ditinjau dari tingkat kemampuan berpikir kreatifnya

Maka dari itu, tujuan penelitian ini adalah:

(1) Menganalisis kesulitan mahasiswa dalam memahami masalah konseptual program linier.

(2) Untuk memberi saran dan solusi pada pembelajaran konseptual program linier.

\section{METODE PENELITIAN}

Pada penelitian ini menggunakan desain penelitian deskriptif. Tujuan pada penelitian ini adalah menganalisisi kesulitan mahasiswa dalam memahami konsep program linier. Subjek penelitian ini merupakan lima mahasiswa semester V Program Studi Pendidikan Matematika STKIP Modern Ngawi tahun ajaran 20202021. Pengambilan subjek berdasarkan tingkat keterampilan berpikir kreatif mahasiswa yang meliputi mahasiswa sangat kreatif, kreatif, cukup kreatif, hampir tidak kreatif dan tidak kreatif. Tahapan pada penelitian ini meliputi analisis hasil tes konsep program linier, wawancara, analisis wawancara, dan catatan lapangan. Instrumen tes yang dikembangkan oleh Van Hiele merupakan konsep program linier seperti mengidentifikasi persoalan dan menyusun model matematika, analisis model, dan merumuskan kesimpulan dan implementasi hasil (of \& 2010, n.d.) (Mashuri, Sudjadi, Pramudya, Gembong, \& Program, 2017).

Teknik untuk mendapatkan validitas data, untuk melihat kevalidan data denagn menggunakan teknik uaraian (1) kredibilitas data dengan cara observasi yang dilakukan secara berkelanjutan (observasi persisten), peneliti melakukan wawancara dengan subjek secara teliti dan mendetail; (2) transferabilitas dengan terus menemukan dan mengumpulkan kejadian empiris dari konteks umum, selanjutnya mendeskripsikannya secara mendetail; (3) keterandalan dengan cara audit yang akan menjaga keaslian dan ketepatan sudut pandang peneliti; (4) kemampuan konfirmasi 
pada isi dengan kebenaran, karena data yang dianalisis merupakan data yang asli dan benar-benar digali serta dipelajari.

\section{HASIL DAN PEMBAHASAN}

Bagian hasil dan pembahasan menyajikan hasil-hasil yang diperoleh dan cara pencapaiannya. Uraian harus komprehensif namun tetap ringkas dan padu. Pembahasan hasil penelitian meliputi kelebihan dan kekurangan, serta pengujian.

Mahasiswa beranggapan bahwa program linier itu sulit membuat mahasiswa lebih cenderung menghindar dari mata kuliah program linier. Pemikiran mahasiswa bisa dipengaruhi oleh proses pembelajaran mata kuliah program linier, yang menyebabkan mahasiswa cenderung kurang serius dalam mengikuti proses pembelajaran. Akhirnya pembelajaran mata kuliah program linier menjadi hafalan tanpa sebuah makna. Proses pembelajaran mata kuliah program linier yang seharusnya menjadi mata kuliah yang dekat dengan kehidupan sehari-hari dianggap hanya selembar kertas yang tidak bermakna. Hal tersebut menimbulkan pembelajaran mata kuliah program linier menjadi tidak menyenangkan, berakibat mulai tercipta kesulitan mahasiswa dalam memahami konsep mata kuliah program linier. Penelitian membahas kesulitan dalam mata kuliah program linier. Kesulitan tersebut didasari oleh kesalahan mahasiswa pada proses menyelesaikan masalah serta menjawab pertanyaan wawancara mengenai masalah yang diberikan.

Kesulitan pada tingkat kemampuan berpikir kreatif adalah sama, pada beberapa kesulitan sebagai contoh mengidentifikasi soal atau masalah yang diberikan, membuat model matematika, serta merumuskan kesimpulan. Namun, kesulitan yang dialami mahasiswa memilili kasus yang berbeda. Mengenai kesulitan "mengidentifikasi masalah", sebagian besar mahasiswa mengatakan "masih kebingungan menentukan variabel $x$ dan variabel $y$ itu yang mana". Alasan yang sesuai yakni mahasiswa belum bisa mengidentifikasi masalah yang diberikan.

Kesulitan selanjutnya yakni analisis pembentukan model matematika dari masalah yang diberikan. Hal tersebut mungkin disebabkan oleh mahasiswa masih cenderung terbiasa mengerjakan soal hitung langsung dan belum menganalisis masalah yang selanjutnya diubah menjadi bentuk matematika. Sebagian mahasiswa 
belum bisa membuat bentuk matematika. Mahasiswa harus mencapai tingkat deduksi informal yakni mahasiswa mampu mengidentifikasi masalah yang diberikan guna untuk mengetahui bentuk matematika dari masalah. Hal tersebut dapat ditunjukan pada Tabel 3.

Tabel 3. Hasil Wawancara dengan Mahasiswa di Setiap Tingkat Keterampilan Berpikir Kreatif dalam Membuat Pemodelan Matematika

\begin{tabular}{cl}
\hline $\begin{array}{c}\text { Kategori } \\
\text { Berpikir Kreatif }\end{array}$ & \multicolumn{1}{c}{$\begin{array}{c}\text { Wawancara } \\
\text { dengan Mahasiswa }\end{array}$} \\
\hline Tingkat 4 & $\begin{array}{l}\text { Merumuskan masalah kedalam bentuk matematika } \\
\text { "dari soal saya membuat persamaan linier ini dan saya } \\
\text { kerjakan dengan eliminasi subtitusi" }\end{array}$ \\
\hline Tingkat 3 & $\begin{array}{l}\text { Merumuskan masalah kedalam bentuk matematika } \\
\text { "setelah membaca soal, saya ubah ke bentuk matematika" }\end{array}$ \\
\hline Tingkat 2 & $\begin{array}{l}\text { Merumuskan masalah kedalam bentuk matematika } \\
\text { "membaca soal dan membuat bentuk matematika pak" }\end{array}$ \\
\hline Tingkat 1 & $\begin{array}{l}\text { Merumuskan masalah kedalam bentuk matematika } \\
\text { "setelah membaca soal, dibuat matematika pak" }\end{array}$ \\
\hline Tingkat 0 & $\begin{array}{l}\text { Merumuskan masalah kedalam bentuk matematika } \\
\text { "bingung pak setelah membaca soal" }\end{array}$ \\
\hline
\end{tabular}

Kesulitan selanjutnya dalam bagaimana mahasiswa mengolah informasi pada soal yang telah diberikan untuk menyimpulkan penyelesaian dari masalah yang diberikan. Pada sebagian mahasiswa masih mengalami kesulitan dalam belajar terkait konsep menganalisis bentuk matematika dari masalah yang diberikan. Mahasiswa masih terbiasa dengan matakuliah yang berhubungan dengan menghitung angka secara langsung. Pada setiap tingkat berpikir kreatif memiliki interprestasi sendiri terhadap konsep penyelesaian program linier yakni ada beberapa cara untuk menyelsaikan masalah program linier 1) metode grafik; 2) metode subtitusi; 3) metode eliminasi; 4) metode gabungan eliminasi subtitusi; 5) metode determinan matriks. Wawancara pada mahasiswa terhadap apa yang diketahui pada soal dan merumuskan dalam bentuk matematika dapat dilihat pada Tabel 4. 
Tabel 4. Hasil Wawancara dengan Mahasiswa di Setiap Tingkat Keterampilan Berpikir Kreatif dalam Menyimpulkan Alternatif Penyelesaian Masalah

\begin{tabular}{cl}
\hline $\begin{array}{c}\text { Kategori } \\
\text { Berpikir Kreatif }\end{array}$ & \multicolumn{1}{c}{ Wawancara dengan Mahasiswa } \\
\hline Tingkat 4 & $\begin{array}{l}\text { Terdapat 5 metode penyelesaian masalah program linier. } \\
\text { "saya menggunakan 2 cara penyelesaian dengan grafik dan } \\
\text { dengan subtitusi eliminasi" }\end{array}$ \\
\hline Tingkat 3 & $\begin{array}{l}\text { Terdapat 5 metode penyelesaian masalah program linier. } \\
\text { "Saya menggunakan cara eliminasi subtitusi" }\end{array}$ \\
\hline Tingkat 2 & $\begin{array}{l}\text { Terdapat 5 metode penyelesaian masalah program linier. } \\
\text { "saya mengerjakan dengan menggunakan cara menggambar } \\
\text { grafik" }\end{array}$ \\
\hline Tingkat 1 & $\begin{array}{l}\text { Terdapat 5 metode penyelesaian masalah program linier. } \\
\text { "saya mengerti soalnya, akan tetapi saya bingung" }\end{array}$ \\
\hline Tingkat 0 & $\begin{array}{l}\text { Terdapat 5 metode penyelesaian masalah program linier. } \\
\text { "saya bingung dengan soalnya" }\end{array}$
\end{tabular}

Berdasarkan penelitian yang dilakukan (Atebe \& Schäfer, 2008) sebagian besar mahasiswa dalam penelitian ini berada di Van Hiele Tingkat 0. Walaupun sedikit banyak yang mampu merumuskan persoalan yang diberikan menjadi bentuk matematika, mahasiswa masih kurang ketika menjelaskan bagaimana mahasiswa mengumpulkan informasi pada soal untuk dirumuskan dalam bentuk matematika. Bagi mahasiswa menghitung angka secara langsung relatif lebih mudah daripada merumuskan masalah kedalam bentuk matematika.

Berdasarkan hasil penelitian, setiap mahasiswa yang tingkat kemampuan berpikir kreatif hanya bisa mencapai pada Tingkat 0 pada mata kuliah program linier berdasarkan Van Hiele, sedangkan pada Tingkat 2 dan Tingkat 3 belum bisa memperoleh prestasi yang baik. Hasil tersebut didukung dengan penelitian (Atebe \& Schäfer, 2008), apakah mahasiswa Pendidikan Matematika di STKIP Modern Ngawi sekedar mampu menyelesaikan masalah secara seadanya tanpa mampu merumuskan masalah matematika serta menyimpulkan penyelesaian masalah yang diberikan. (Atebe \& Schäfer, 2008) memberikan bukti bahwa kasus tersebut merupakan masalah kesalahpahaman yang berasal dari analisis masalah yang kurang tepat, seperti menentukan variabel-variabel pada masalah yang akan digunakan untuk merumuskan dalam bentuk matematika. 
(Ma, Lee, Lin, Mathematics, \& 2015, n.d.) berpendapat bahwa mahasiswa mengalami kesulitan dalam merumuskan persoalan kedalam bentuk matematika yang jarang sekali ada dalam buku teks ataupun dikehidupan mereka sehari-hari. Berdasarkan hasil penelitian ini menunjukan bahwa mahasiswa tidak bisa mengidentifikasi masalah yang diberikan, yang berakibat mahasiswa kesulitan dalam menyusun masalah kedalam bentuk matematika.

Sejalan dengan apa yang dikemukanan (Ma et al., n.d.) tingkatan esensial ini mempunyai makna deduksi dalam Teori Van Hiele yang belum dipahami mahasiswa. Namun merumuskan masalah dalam bentuk matematika pada tingkat ini diartikan bahwa mahasiswa mampu mencari informasi yang terkandung dalam masalah untuk membuat model matematika yang selanjutnya akan dicari solusinya. Pada sebagian besar mahasiswa belum mampu untuk memilih metode-metode penyelesaian masalah program linier pada setiap tingkat keterampilan berpikir kreatif.

Berdasarkan uraian yang telah disampaikan bisa disimpulkan dalam memahami konsep penyelesaian masalah program linier mahasiswa masih mengalami kesulitan. Kesulitan muncul tidak hanya dialami mahasiswa tidak kreatif, akan tetapi pada semua mahasiswa pada tingkat kemampuan berpikir kreatif juga mengalaminya. Sejalan dengan penelitian yang dilakukan oleh (Widdiarto, n.d.) bahwa semua mahasiswa dengan beberapa tingkat kemampuan berpikir kreatif mengalami kesulitan belajar. Kesulitan mahasiswa pada konsep penyelesaian masalah program linier sebagian besar merasa kesulitan dalam proses mengerjakan masalah yang diberikan, hal tersebut dikarenakan mahasiswa masih belum memahami materi program linier. Disisi lain kurang ketelitian mahasiswa dalam mengerjakan masalah yang diberikan serta terlalu terburu-buru ingin segera selesai yang mengakibatkan mahasiswa sering tidak mengecek pekerjaan mereka kembali.

(Rianti, 2018) mengungkapkan bahwa rendahnya keterampilan pemecahan masalah matematika tersebut disebabkan karena sebagian besar mahasiswa masih kesulitan ketika menyelesaikan masalah-masalah yang tidak rutin terlebih pada soal cerita. Mahasiswa ketika diberikan masalah yang berupa soal cerita, mahasiswa kurang mampu menganalisis masalah yang diberikan sehingga kesulitan dalam merumuskan bentuk matematikanya dan berakibat mahasiswa akan kesulitan untuk menentukan metode penyelesaian dan penyelesaian dari masalah. Sejalan dengan itu 
hasil penelitian (Akbar, Hamid, Bernard, Sugandi, \& Siliwangi, 2018) (Mashuri, ..., \& 2019, n.d.) pada tahap wawancara dapat dilihat bahwa mahasiswa mengalami kesulitan adalah sebagian besar mahasiswa tidak terbiasa ketika menuliskan informasi yang terkandung dalam soal, data apa saja yang tidak ada? Dapa apa yang didapatkan? Bagaimana kondisinya? Serta mahasiswa lebih cenderung menyelesaikan masalah dengan cara langsung kareana mahasiswa beranggapan bahwa hal tersebut tidak perlu dilakukan menuliskan langkah-langkah peyelesaian karena akan membuang waktu.

\section{SIMPULAN}

Tingkat keterampilan berpikir kreatif mahasiswa tidak ada signifikansi dengan kesulitan mahasiswa dalam menyelesaikan masalah terkait program linier. Hal tersebut disebabkan disetiap tingkat keterampilan berpikir kreatif mahasiswa selalu banyak kesulitan. Kesulitan mahasiswa untuk menyelesaikan masalah antara lain: 1) pemahaman mahasiswa dalam mengidentifikasi masalah sangat kurang. 2) pemahaman mahasiswa dalam menyusun masalah ke bentuk matematika; dan 3) ketidak hati-hatian dalam proses penyelesaian masalah.

\section{REFERENSI}

Akbar, P., Hamid, A., Bernard, M., \& Sugandi, A. I. 2017. Analisis Kemampuan Pemecahan Masalah Dan Disposisi Matematik Siswa Kelas Xi Sma Putra Juang Dalam Materi Peluang. Jurnal Cendekia: Jurnal Pendidikan Matematika, 2(1), 144-153. https://doi.org/10.31004/cendekia.v2i1.62

Alghafri, A., Social, H. I.-I. J. of. 2014, undefined. (n.d.). The effects of integrating creative and critical thinking on schools students' thinking. Pdfs.Semanticscholar.Org. Retrieved April 2, 2021, from https://pdfs.semanticscholar.org/f1b5/b648c9f5c81bd179a3357dc770a57bb bb6b2.pdf. Pada 20 Februari 2018

Atebe, H. U., \& Schäfer, M. 2008. "As soon as the four sides are all equal, then the angles must be $90^{\circ}$ each". children's misconceptions in geometry. African Journal of Research in Mathematics, Science and Technology Education, 12(2), 47-65. https://doi.org/10.1080/10288457.2008.10740634

Ayşen, Ö. 2012. Misconceptions in geometry and suggested solutions for seventh grade students. Elsevier-Procedia-Social and Behavioral, 55, 720-729. 
https://doi.org/https://doi.org/10.1016/j.sbspro.2012.09.557

De Villiers, M. 2012. Some Reflections on the Van Hiele theory. In National Mathematics Congress (Issue May, pp. 21-23).

Erdogan, T., Akkaya, R., \& Akkaya, S. Ç. 2009. Th e Eff ect of the Van Hiele Model Based Instruction on the Creative Th inking Levels of 6th Grade Primary School Students. In ERIC (Vol. 9, Issue 1). https://eric.ed.gov/?id=EJ837779

Hsiu-Lan, M., De-Chih, L., Szu-Hsing, L., \& Der-Bang, W. 2015. A Study of Van Hiele of Geometric Thinking among 1st through 6th Graders. EURASIA J Math Sci Tech Ed, 11(5), 1181-1196. https://doi.org/doi.org/10.12973/eurasia.2015.1412a

Irawati, S. 2015. Analisis Kesalahan Mahasiswa Calon Guru Matematika dalam Memecahkan Masalah Program Linier. Sigma, 1(1), 29-34. http://ejournal.unira.ac.id/index.php/jurnal_sigma/article/viewFile/110/94

Mashuri, A., Rahmawati, A. D., \& Cahyono, H. 2019. Kemampuan representasi matematis siswa dalam pemecahan masalah trigonometri ditinjau dari kompetensi pengetahuan. Jurnal Karya Pendidikan, 6(2), 59-65. http://103.97.100.145/index.php/JPMat/article/view/5087

Mashuri, A., Sudjadi, I., Pramudya, I., \& Gembong, S. 2017. Student Analogy Reasons When Solving Area Concepts in Pyramids and Prisms. Journal of Physics: Conference Series, 895(1), 12041. https://doi.org/10.1088/17426596/895/1/012041

Rianti, R. 2018. Profil Kemampuan Pemecahan Masalah Matematis Siswa SMP Pada Materi Bangun Ruang Sisi Datar. Jptam.Org, 2. https://www.jptam.org/index.php/jptam/article/view/27

Silver, E. A. 1997. Kreativität fördern durch einen unterricht, der reichist and situationen des mathematischen problemlösens und aufgabenerfindens. International Journal on Mathematics Education, 29(3), 75-80. https://doi.org/10.1007/s11858-997-0003-x

Siswono, T. Y. E. 2011. Level of student's creative thinking in classroom mathematics. Educational Research and Reviews, 6(7), 548-553.

Taha, H. 1996. Riset Operasi: suatu pengantar, jilid 1. In Binarupa Aksara.

Vinet, L., \& Zhedanov, A. 2011. A “missing" family of classical orthogonal polynomials. Journal of Physics A: Mathematical and Theoretical. https://doi.org/10.1088/1751-8113/44/8/085201 